\title{
Stable isotope study through the Permian-Triassic boundary in East Greenland
}

\author{
LARS CLEMMENSEN, W. T. HOLSER \& D. WINTER
}

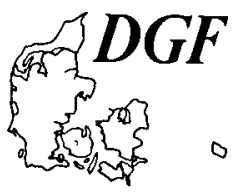

\begin{abstract}
Clemmensen, L. B., Holser, W. T. \& Winter, D.: Stable isotope study through the Permian-Triassic boundary in East Greenland. Bull. geol. Soc. Denmark, vol. 33, pp. 253-260, Copenhagen, February, 28th, 1985.

A survey of stable isotope ratios in sediments spanning the Permian-Triassic boundary in East Greenland shows Upper Permian evaporites to have $\delta^{34} \mathrm{~S}=+10.6 \pm 1.6 \%$ and limestones to have $\delta^{13} \mathrm{C}_{\text {carb }}=+4.5 \pm$ $0.4 \%$, in conformity with similar values from probable correlative formations in Europe and North America. Most values of both isotopes in Triassic formations are lower and scattered, apparently reflecting varying inputs of non-marine waters including the oxidative erosion of isotopically light sulfur. This transition in the East Greenland section has obscured any clear detection of chemical events recorded elsewhere: a drop in marine $\delta^{13} C_{\text {carb }}$ near the Permian-Triassic boundary, and a sharp rise in $\delta^{34} S_{\mathrm{stt}}$ in latest Scythian time.
\end{abstract}

L. B. Clemmensen, Institute of General Geology, Øster Voldgade 10, DK-1350 Copenhagen K, Denmark, W. Holser, University of Oregon, Eugene, OR 97403, USA, D. Winter, Department of Geology, University of California, Los Angeles, CA 90024, USA, March 16th, 1984.

\section{Introduction}

Although the general forms of the isotope age curves through Phanerozoic time of sulfur isotopes $\left(\delta^{34} S_{\text {stt }}\right)$ in marine evaporites (Claypool, Holser, Kaplan, Sakai \& Zak 1980) and of carbon isotopes in marine limestones (Veizer, Holser \& Wilgus 1981; Lindh, Saltzman, Sloan, Mattes \& Holser 1981) have been described, the details of short-term changes in these curves are as yet little known (Holser 1977; Scholle \& Arthur 1980). In particular, possible isotope shifts associated with the Paleozoic-Mesozoic era boundary have been investigated for carbon only in the western USA (Wilgus 1981), and additionally for sulfur in northwestern Europe (Claypool et al. 1980). Inasmuch as East Greenland exposes one of the classic sections spanning this interval, we have made a reconnaissance of possible isotope variations using samples from the collections of the Geological Survey of Greenland. This area was of particular interest because of the completeness of the section, its distance from sections previously studied, and because of its correlation with the Zechstein sections of northwestern Europe.
Palaeogeography, stratigraphy, and sampling

The section in East Greenland (fig. 1) lies alongside the seaway that fed the basins of northwestern Europe with Arctic marine waters throughout the Permian, possibly continuing into the Griesbachian (Callomon, Donovan \& Trümpy 1972). Later in Triassic times any connection of the Arctic to Europe via East Greenland is problematic (Callomon et al. 1972; Warrington 1970). Much of the Triassic in East Greenland is a red-bed sequence with palaeontological and sedimentilogical evidence of continental origin (Clemmensen 1978, 1980), so the Arctic marine source may not have reached there. However, in other basins some evaporites and limestones have been found to be dominantly of marine derivation even though enclosed in red beds. Consequently we have analysed the whole East Greenland section without a priori decision as to whether their chemical components were of marine or continental origin.

The stratigraphic relations and lithology of formations and members sampled in the Upper Permian and the Triassic of East Greenland are out- 


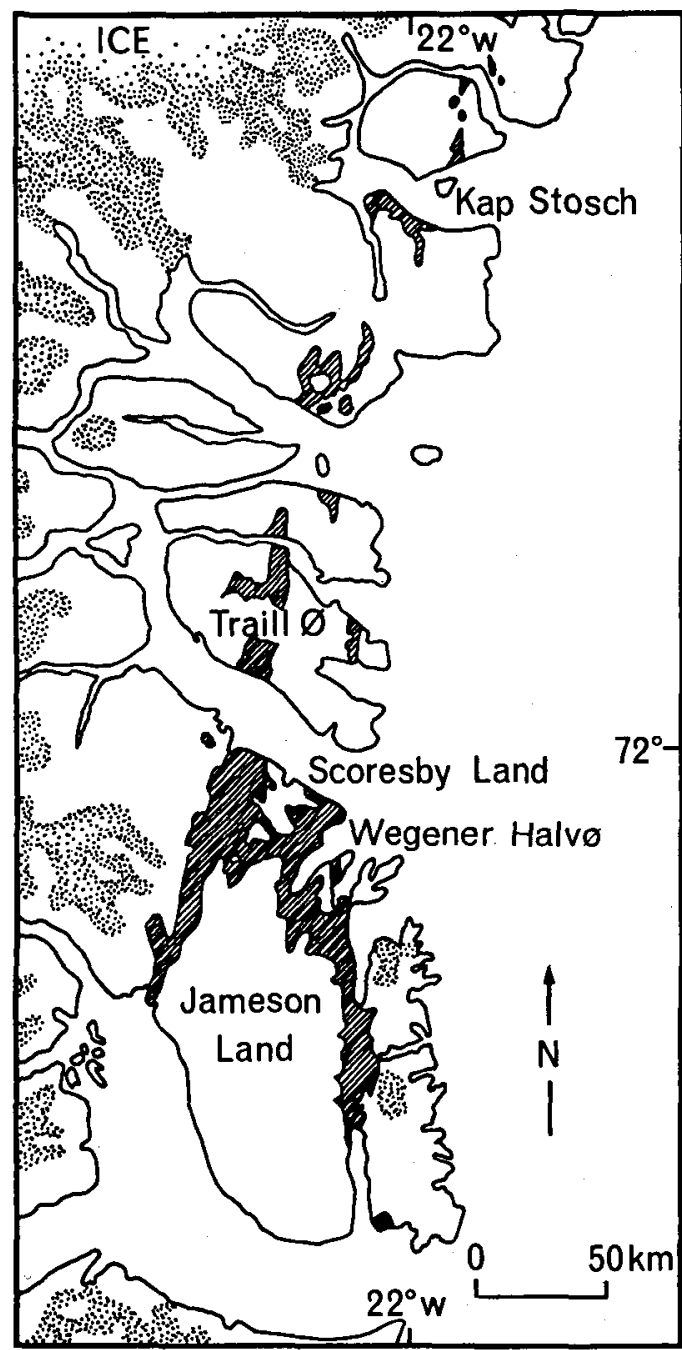

Fig. 1. The distribution of Upper Permian and Triassic sedimentary rocks in central East Greenland.

lined in table 1 (Birkelund \& Perch-Nielsen 1976; Clemmensen 1980; Grasmück \& Trümpy 1969; Maync 1942, 1961; Perch-Nielsen, Birkenmajer, Birkelund \& Aellen 1974). The Upper Permian Foldvik Creek Formation (Birkelund \& PerchNielsen 1976) consists mainly of a number of shallow marine facies associations, one of which is characterised by finely laminated gypsum (Surlyk, Piasecki, Rolle, Stemmerik, Thomsen \& Wrang, in press). The overlying Lower Scythian Wordie Creek Formation is composed of shallow marine sandstones and siltstones, which only rarely are gypsum-bearing. During Scythian time the depositional regime apparently shifted rather abruptly to one that was dominantly continental: the Upper Scythian (?) to Lower Rhaetian (?) Pingo Dal, Gipsdalen and Fleming Fjord Formations were deposited mainly in environments described as alluvial fan, fluvial, aeolian, sabkha and lacustrine (Clemmensen 1978, 1980). Gypsum occurs as centimeter-sized nodules, millimeter to centimeter thin veins, massive layers (up to ca. $30 \mathrm{~cm}$ ) and sand-sized particles (often forming cross-bedding) in the Kolledalen, Solfaldsdal and Kap Seaforth Members of the Gipsdalen Formation. Rock salt pseudomorphs are common in the Kap Seaforth Member, but also occur rarely in the overlying Edderfugledal Member (Table 1). Palaeontological affinities are mainly with the Zechstein to the south in the Late Permian, and with Arctic Canada in the Scythian; in the rest of Triassic time fossils are sparse and mainly nonmarine. A mixture of Permian and Triasłic faunas in the basal part of the Wordie Creek Formation, and its apparent conformity with the underlying Foldvik Creek Formation, has led to controversial assertions that deposition was continuous across the era boundary, but mainly on sedimentological grounds current opinion favours a hiatus during the Latest Permian (Teichert \& Kummel 1973; Flügel 1973). That determination is supported by a local erosional unconformity at the base of the Lower Triassic (Birkenmajer 1977). Thus although the Foldvik Creek Formation seems to be correlated with the Zechstein Series, which is the latest Permian represented in northern Europe, the correlation of the Zechstein itself is vague (e.g. Visscher 1973) in relation to both the type section and the best documented Permian sections in central Asia, and latest Permian may be absent in both western Europe and eastern Greenland. The Foldvik Creek Formation has only one major evaporite unit, and there is no information as to which of the four to six evaporite cycles of the Zechstein it may be correlative.

The samples analysed are listed in Tables 2 and 3 , and include most of the evaporitic and limestone horizons from the gypsum facies of the Upper Permian (mainly Kazanian; Piasecki, pers. comm. 1984) Foldvik Creek Formation through the Ladinian (?) Kap Seaforth Member of the Gipsdalen Formation. 
Table 1

Upper Permian and Triassic stratigraphy of East Greenland

\begin{tabular}{|c|c|c|c|c|c|}
\hline \multicolumn{3}{|c|}{ Stage } & Formation & Member & Lithology (evaporites in italics) \\
\hline \multicolumn{3}{|c|}{ Norian } & & Orsted Dal & $\begin{array}{l}125-250 \mathrm{~m} \text {; fluvial conglomerates and sandstones; } \\
\text { non-marine trace fossils; marine limestones at top. }\end{array}$ \\
\hline \multirow{2}{*}{\multicolumn{3}{|c|}{ Carnian(?) }} & $\begin{array}{l}\text { Fleming } \\
\text { Fjord }\end{array}$ & Malmros Klint & $\begin{array}{l}30-225 \mathrm{~m} \text {; lacustrine fine sandstones and } \\
\text { siltstones; non-marine trace fossils. }\end{array}$ \\
\hline & & & & Edderfugledal & $\begin{array}{l}\text { 40-130 m; lacustrine dolostones, stromatolites, } \\
\text { sandstones and siltstones; rare rock salt } \\
\text { pseudomorphs; non-marine trace fossils. }\end{array}$ \\
\hline \multicolumn{3}{|c|}{ Ladinian(?) } & & Kap Seaforth & $\begin{array}{l}\text { 20-160 m; lacustrine sandstones, siltstones, and } \\
\text { gypsum; common rock salt pseudomorphs. }\end{array}$ \\
\hline \multicolumn{3}{|c|}{ Anisian (?) } & & $\begin{array}{l}\text { Solfaldsdal/ } \\
\text { Kolledalen }\end{array}$ & $\begin{array}{l}\text { 50-165 m; aeolian, fluvial and lacustrine sandstones } \\
\text { and siltstones with gypsum; non-marine trace } \\
\text { fossils; intercalation of marine limestones }(0-35 \mathrm{~m})\end{array}$ \\
\hline \multirow{2}{*}{ 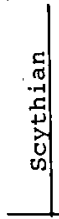 } & \multirow{2}{*}{$\begin{array}{cc}1 & \\
\text { in } & 1 \\
0 & \frac{1}{0} \\
-1 & 0 \\
-10 & 0 \\
0 & 0 \\
\end{array}$} & 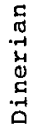 & Pingo Dal & $\begin{array}{l}\text { Klitdal/ } \\
\text { Paradigmabjerg/ } \\
\text { Rødstaken }\end{array}$ & $\begin{array}{l}70-700 \mathrm{~m} \text {; fluvial conglomerates, arkose and } \\
\text { sandstones; non-marine trace fossils; locally beds } \\
\text { of limestone at top with marine microfossils. }\end{array}$ \\
\hline & & 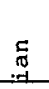 & $\begin{array}{l}\text { Wordie } \\
\text { Creek }\end{array}$ & $\begin{array}{l}{[8 \text { faunal }} \\
\text { zones] }\end{array}$ & $\begin{array}{l}70-700 \mathrm{~m} ; \text { marine sandstones, siltstones and shales; } \\
\text { minor gypsum. }\end{array}$ \\
\hline \multicolumn{3}{|c|}{$\begin{array}{l}\text { Kazanian - } \\
\text { Tatarian }\end{array}$} & $\begin{array}{l}\text { Foldvik } \\
\text { Creek }\end{array}$ & $\begin{array}{l}\text { [5 facies } \\
\text { associations] }\end{array}$ & $\begin{array}{l}\text { 50-300 } \mathrm{m} \text {; marine limestones, shales, sandstones and } \\
\text { gypsum; fluvial conglomerates at base. }\end{array}$ \\
\hline
\end{tabular}

\section{Analytical methods}

For sulfur isotope analysis, gypsum was picked from hand samples. All samples were crushed to 42 mesh, dissolved in $6 \mathrm{~N} \mathrm{HCl}$ and filtered with Millipore filters $(0.45 \mu \mathrm{m})$. The solutions were precipitated with $10 \% \mathrm{BaCl}_{2}$ and allowed to stand overnight; precipitated $\mathrm{BaSO}_{4}$ was filtered, washed, and dried. $\mathrm{SO}_{2}$ for the mass spectrometer was prepared by firing the $\mathrm{BaSO}_{4}$ with organic-free quartz powder, and the purified gases were analysed on a Nuclide RMS 6-60 Mass Spectrometer against Canyon Diablo $\mathrm{SO}_{2}$.

For carbon isotope analysis pure limestones, for the most part micritic, were crushed and sieved to 42-100 mesh, reacted with hypochlorite overnight to remove organic carbon, and centrifuged with distilled water until neutral. About $10 \mathrm{mg}$ of dried sample was reacted under vacuum with $100 \% \mathrm{H}_{3} \mathrm{PO}_{4}$ at $25 \mathrm{C}$ for 24 hours. The $\mathrm{CO}_{2}$ evolved was purified and analysed on a Finnigan MAT 250 mass spectrometer.

Analytical results are expressed in the customary per-mil deviation $(\delta)$ relative to standards of
Canyon Diablo troilite for sulphur and Pee Dee Belemnite for carbon. Precision of the isotope analysis is $\pm 0.1 \%$ for $C$ and $O$, and $\pm 0.3 \%$ for $S$.

\section{Results and discussion}

The results are tabulated in tables 2 and 3, and summarized in fig. 2 .

The sulfur isotope analyses fall into two rather distinct groups: the Upper Permian and Scythian samples with $\delta^{34} \mathrm{~S}=+10.6$ to $13.5 \%$, and the overlying later Triassic samples with $\delta^{34} \mathrm{~S}=-0.2$. to $+8.2 \%$. As expected, the values from the Upper Permian Foldvik Creek Formation are consistent with the very large number of previous determinations on marine Upper Permian evaporites, in both the Zechstein Series throughout western Europe and the Ochoan Series of the USA, with $\delta^{34} \mathrm{~S}=+11 \pm 1.5 \%$ (Claypool et al. 1980). The determination of $\delta^{34} S=+13.5 \%$ for the single Scythian sample also mimics the slight rise in the earliest Triassic previously found in 
Table 2. Isotope analyses of Triassic rocks from East Greenland.

(For locations see Perch-Nielsen et al. 1974; Clemmensen 1980).

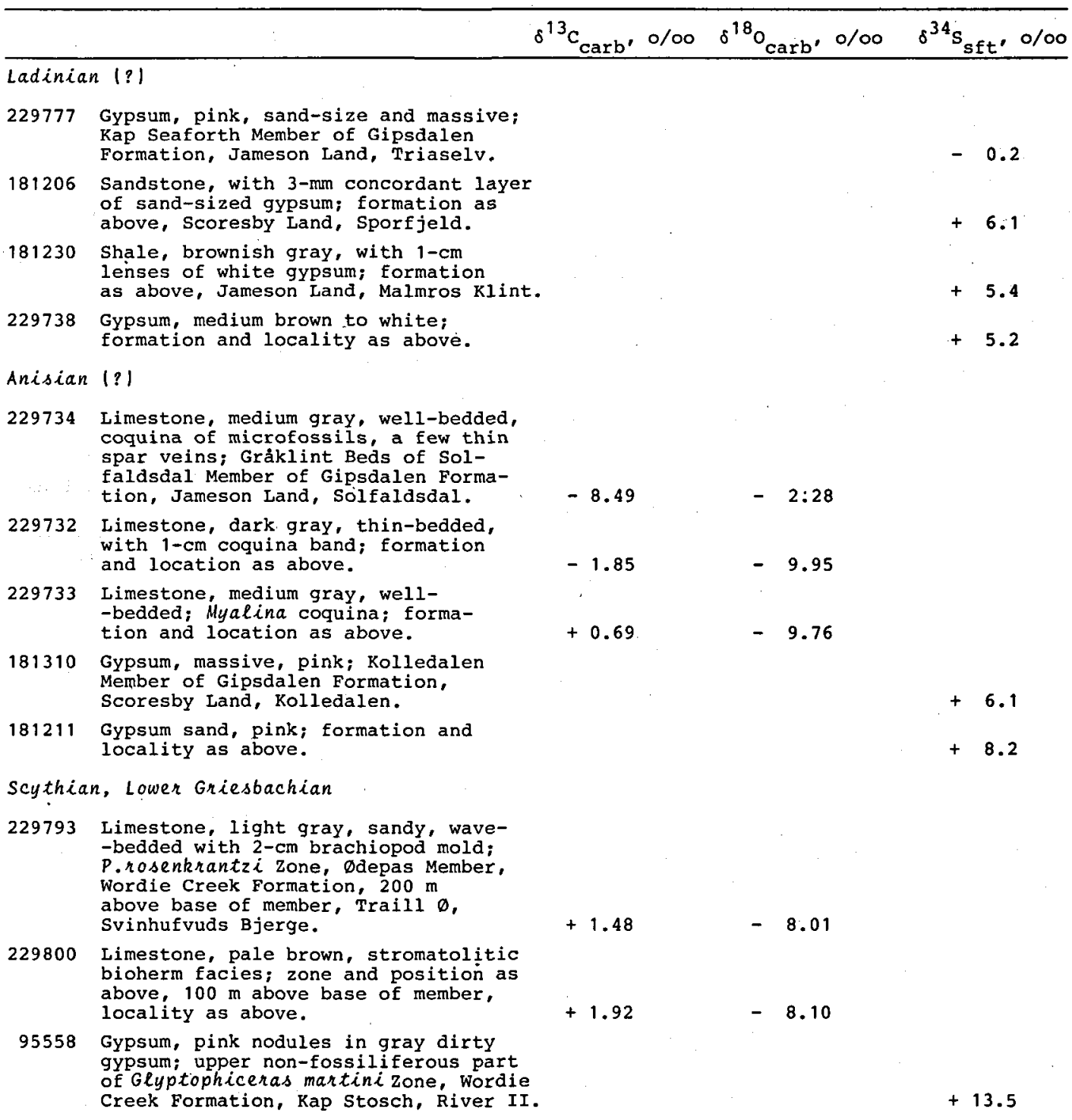

samples from both Germany (summarized in Claypool et al. 1980) and the Western Interior, USA (Wilgus 1981).

Most of the Anisian-Ladinian sulfates are lighter than any marine sulfate of any age previously analysed, and in particular they are much ligther than the range of $\delta^{34} S=+15$ to $+23 \%$ previously found for marine evaporites of this age. Low values of $\delta^{34} \mathrm{~S}$ are expected in nonmarine evaporites that are fed by streams having a mixture of sulfate from older evaporites $\left(\delta^{34} S=\right.$
$+20 \pm 10 \%$ ) and oxidized sulfide from shales $\left(\delta^{34} \mathrm{~S}=-17+10 \%\right.$ o $)$ or igneous rocks $\left(\delta^{34} \mathrm{~S}=+1\right.$ $\pm 2 \%$ ), although only a few non-marine evaporites have been analysed for isotopes previously (Permian Rotliegend, Holser 1977; Permian Kupferschiefer, Marowsky 1969; Triassic Keuper, Taylor 1983; Eocene of the Paris Basin, Boch, Marcé \& Mégnien 1974; Pleistocene Searles Lake, Holser \& Kaplan 1966). The Gipsdalen Formation is of generally non-marine aspect, except for a thin intercalation of marine 
Table 3. Isotope analysès of Permian rocks from East Greenland.

\begin{tabular}{|c|c|c|c|c|}
\hline & $\delta^{13}$ & $c_{\text {carb }}, 0 / 00$ & $\delta^{18} o_{\mathrm{Carb}}, 0 / 00$ & $\delta^{34} s_{s f t}, 0 / 00$ \\
\hline \multicolumn{5}{|c|}{ Kazanian - Tatarian (zechstein) } \\
\hline 234953 & $\begin{array}{l}\text { Limestone, medium brown, poorly } \\
\text { bedded, with many well-preserved } \\
\text { macrofossils; some thin span veins } \\
\text { (not analysed); Martinia Limestone } \\
\text { Member, Foldvik Creek Formation, } \\
\text { Wegener Halvø. }\end{array}$ & -5.27 & -7.42 & \\
\hline 269159 & $\begin{array}{l}\text { Limestone, pale yellowish brown, } \\
\text { massive, fossil fragments, non- } \\
\text {-reef facies; Limestone-Dolomite } \\
\text { Member, Foldvik Creek Formation, } \\
\text { Jameson Land, Schuchert Dal. }\end{array}$ & +5.28 & -9.16 & \\
\hline 269145 & Limestone, as above. & +4.94 & -8.33 & \\
\hline 234908 & $\begin{array}{l}\text { Limestone, brownish gray, fine } \\
\text { grained, reef facies; Limestone- } \\
\text {-Dolomite Member, Wegener Halvø. }\end{array}$ & +4.22 & -12.49 & \\
\hline 234903 & $\begin{array}{l}\text { Limestone, light gray, fine grained, } \\
\text { reef facies; Limestone-Dolomite } \\
\text { Member, Wegener Halvø. }\end{array}$ & +4.36 & -10.31 & \\
\hline 234902 & $\begin{array}{l}\text { Limestone, greenish gray, coarsely } \\
\text { fossiliferous, reef facies; forma- } \\
\text { tion and location as above. }\end{array}$ & +4.51 & -10.68 & \\
\hline 234901 & $\begin{array}{l}\text { Limestone, brownish green, coarsely } \\
\text { fossiliferous, reef facies; forma- } \\
\text { tion and location as above. }\end{array}$ & +4.18 & -11.33 & \\
\hline 269191 & $\begin{array}{l}\text { Limestone, medium brown, stromatolitic; } \\
\text { uncertain member of Foldvik Creek } \\
\text { Formation, Jameson Land, Schuchert Dal. }\end{array}$ & +5.10 & -5.00 & \\
\hline 111199 & $\begin{array}{l}\text { Gypsum, white, massive; Gypsum Member, } \\
\text { Foldvik Creek Formation, Scoresby Land, } \\
\text { Werner Bjerge. }\end{array}$ & & & +12.2 \\
\hline 111159 & $\begin{array}{l}\text { Gypsum, white, massive; formation as } \\
\text { above; Scoresby Land, Werner Bjerge, } \\
\text { Malmbjerg. }\end{array}$ & & & +11.6 \\
\hline 269125 & $\begin{array}{l}\text { Gypsum, white, massive; formation as } \\
\text { above, Jameson Land, Schuchert Dal. }\end{array}$ & & & +9.3 \\
\hline 269219 & As above. & & & +9.1 \\
\hline
\end{tabular}

limestone (the Gråklint Beds; Clemmensen 1980). Stauber (1942) and Perch-Nielsen et al. (1974) supposed that the gypsum depositum was lagoonal. An analysis of sedimentary features by Clemmensen (1978) concluded that the gypsum was deposited in dune and inland sabkhas, and our sulfur isotope data confirm such a non-marine regime of deposition. Clemmensen (1978) also speculated that while some of the evaporite may have been wind-blown "cyclic" marine salt (which would also have contributed sulfate), the major source was erosion of Permian gypsum exposed in the western borderlands of the basin. The sulfur isotope data indicate, however, that sulfide, presumably from the weathering of shales, was a major component of the source sulfur.
Unfortunately none of the marine evaporites in East Greenland are young enough to record the very high $\delta^{34} S$ of the Röt Event (Holser 1977).

The high values of $\delta^{13} \mathrm{C}=+4.2$ to $5.3 \%$ from limestones in the Limestone-Dolomite Member of the Foldvik Creek Formation are in excellent agreement with similarly high $\delta^{13} \mathrm{C}$ previously described in detailed sections above the base of the Zechstein Series in northwestern Europe (Margaritz \& Schulze 1980; Margaritz \& Turner 1982), the Ochoan Series of the western USA (Magaritz, Anderson, Holser, Saltzman \& Garber 1983), and the Bellerophon Formation of the Dolomite-Carnic Alps (Holser \& Magaritz 1984), and the Changxing Formation of southern China (Chen, Shao, Huo \& Yao 1984).

Values of $\delta^{13} \mathrm{C}$ in all the younger formations 


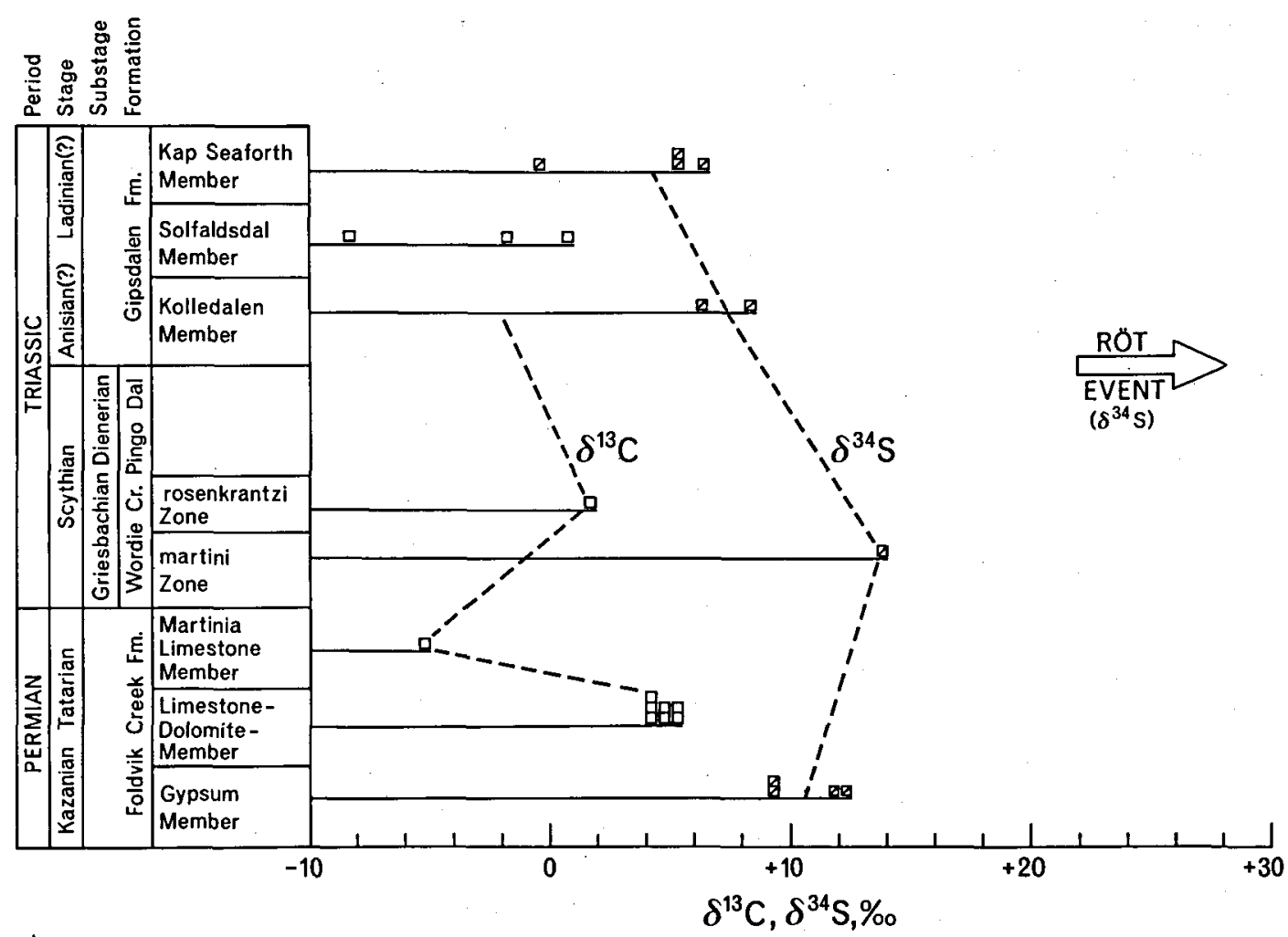

Fig. 2. Variations of stable isotope ratios of carbon and sulfur (per mil relative to PDB and Canyon Diablo, respectively) through the Permian-Triassic interval in East Greenland. The vertical axis is not to time scale; the timing of the Röt Event detected elsewhere is indicated.

sampled are lower, but scattered - while four are within the moderate values of $\delta^{13} \mathrm{C}=0 \pm 2 \%$ expected from limited experience with Triassic marine limestone (Lindh et al. 1981; Wilgus 1981), two others are substantially lower and may reflect non-marine contributions (like the $\delta^{34} \mathrm{~S}$ ) or meteoric waters. Certainly all of the limestone measurements for $\delta^{18} \mathrm{O}_{\text {carb }}$ show values so low, -5 to $-12 \%$, that the oxygen in the carbonates which exchanges much more easily than the carbon (Magaritz 1983), perhaps exchanged with meteoric waters of the present high-latitude outcrops. Thus while these data from East Greenland affirm the high ${ }^{13} \mathrm{C}$ of marine carbonate found elsewhere in the Upper Permian, neither the timing nor magnitude of a drop into the Early Triassic can be discerned.

\section{Conclusions}

In a survey of the Upper Permian through Triassic sediments of East Greenland, $\delta^{34} S_{\text {sft }}=$ $+10.6 \pm 1.6 \%$ in evaporite formations and $\delta^{13} \mathrm{C}_{\text {carb }}=+4.5 \pm 0.4 \%$ in limestone formations of Late Permian age confirm similar values previously determined in correlative marine sections in Europe and North America. Triassic values of both isotopes are generally lower and scattered, apparently reflecting varying inputs of non-marine waters in accord with determinations from previous sedimentological studies. Neither a drop in $\delta^{13} \mathrm{C}$ near the Permian-Triassic boundary, nor the sharp rise in $\delta^{34} S$ in the Early TriassicSmithian (Röt Event) are evident because of the marine-non-marine transition. 
Acknowledgments. Holser canvassed European and world Permo-Triassic stratigraphic correlations during a stay at the Geochemisches Institut, Universität Göttingen, under a Senior U.S. Scientist Grant from the Alexander von Humboldt Stiftung. Further support was provided by the U.S. National Science Foundation under Grant EAR 815985. Clemmensen received a grant from the Danish Natural Science Research Council while working with the Triassic in East Greenland. We direct our thanks to Tove Birkelund and Fin Surlyk, who read the paper critically. L. Stemmerik collected most of the Permian samples and Tove Birkelund furnished some of the Triassic samples. The paper is published with the permission of the Director of the Geological Survey of Greenland.

\section{Dansk Sammendrag}

Stabile isotop forhold $\mathrm{i}$ sedimenter fra $\emptyset$ vre Perm samt Nedre og Mellem Trias fra det centrale Østgrønland er blevet undersøgt. Evaporitter fra Øvre Perm har $\delta^{34} S=+10.6 \pm 1.6 \%$ og kalksten har $\delta^{13} \mathrm{C}_{\text {carb }}=+4.5 \pm 0.4 \%$ i overensstemmelse med de vardier, der kendes fra Øvre Perm sedimenter i Europa og Nordamerika. Sedimenter fra begyndelsen af Nedre Trias har også høje isotopværdier svarende nøje til dem, der kendes fra andre lokaliteter. Derimod har de overliggende Trias sedimenter lave og spredte isotopværdier både for $\delta^{34} \mathrm{~S}$ og $\delta^{13} \mathrm{C}_{\text {carb }}$. Disse lave vardier tolkes som resultat af tilførsel af ferskvand samt isotopisk set lette sulfider til sedimentationsbassinet i Mellem Trias. Isotopundersøgelsen af de Permo-Triassiske sedimenter har derfor ikke kunnet vise det normale marine udviklingsmønster, der kendes fra andre lokaliteter og omfatter et fald i $\delta^{13} C_{\text {carb }}$ nær Perm-Trias grænsen og en pludselig stigning i $\delta^{34} S_{\text {stt }}$ i slutningen af nedre Trias.

\section{References}

Birkelund, T. \& Perch-Nielsen, K. 1976: Late Paleozoic-Mesosoic evolution of central East Greenland, in A. Escher \& W. S. Watt (eds) Geology of Greenland. Copenhagen: Grønlands geologiske Unders $\emptyset$ gelse, 305-339.

Birkenmajer, K. 1977: Erosional unconformity at the base of the marine Lower Triassic at Wegener Halvø, central Greenland. Rapp. Gronlands geol. Unders. 85, 103-107.

Bosch, B., Marcé, A. \& Mégnien, C. 1974: Observations sur la zonalité de le composition isotopique du soufre des gypses du Ludien du Bassin de Paris. Bull. Inform. Geol. Bassin Paris 41, 31-34.

Callomon, J. H., Donovan, D. T. \& Trümpy 1972: An annotated map of the Permian and Mesozoic formations of east Greenland. Meddr Grønland 168(3), 35 pp.

Chen, J., Shao, M., Huo, W. \& Yao, Y. 1984: Carbon isotope of carbonate strata at Permian-Triassic boundary in Changxing. Zhejian. Scientia Geol. Sinica, 1984, no. 1, 8893.

Claypool, G. E., Holser, W. T., Kaplan, I. R., Sakai, H. \& $\mathrm{Zak}, \mathrm{I}$. 1980: The age curves of sulfur and oxygen isotopes in marine sulfate and their mutual interpretation. Chem. Geol. 28, 199-259.

Clemmensen, L. B. 1978: Alternating aeolian, sabkha, and shallow-lake deposits from the Middle Triassic Gipsdalen Formation, Scoresby Land, East Greenland. Palaeogeog. Palaeoclimat. Palaeoecol. 24, 24-111.

Clemmensen, L. B. 1980: Triassic rift sedimentation and palaeogeography of central East Greenland. Bull. Grønlands geol. Unders. 136, 72 pp.
Flügel, H. W. 1973: Rugose Korallen aus dem Ober-Perm von Ostgrönland. Geol. Bundesanst. Wien Verhandl., 1-57.

Grasmück, K. \& Trümpy 1969: Notes on Triassic stratigraphy and paleontology of north-eastern Jameson Land (East Greenland). I. Triassic stratigraphy and general geology of the country around Fleming Fjord (East Greenland). Meddr. Grønland 168(2), 5-71.

Holser, W. T. 1977: Catastrophic chemical events in the history of the ocean. Nature 267, 403.

Holser, W. T. 1977: Rotliegend evaporites, Lover Permian of northwestern Europe - geochemical confirmation of the non-marine origin. Erdöl Kohle Erdgas Petrochemie 32, 159-162.

Holser, W. T. \& Kaplan, I. R. 1966: Isotope geochemistry of sedimentary sulfates. Chem. Geol. 1, 93-135.

Holser, W. T. \& Magaritz, M. 1984: Late Permian carbon isotope anomaly in the Bellerophon Basin, Carnic and Dolomite Alps. Jahrb. Geol. Bundesanst. Wien (submitted).

Lindh, T. B., Saltzman, E. S., Sloan, J. J., II, Mattes, B. W. \& Holser, W. T. 1981: A revised $\delta^{13} \mathrm{C}$-age curve. Geol. Soc. Amer. Abstr. Prog. 13, 498.

Magaritz, M. 1983: Carbon and oxygen isotope composition of recent and ancient coated grains, in T. M. Peryt (ed) Coated Grains, Springer Verlag, Berlin, 27-37.

Magaritz, M., Anderson, R. A., Holser, W. T., Saltzman, E. S. \& Garber, J. 1983: Isotope shifts in the Late Permian of the Delaware Basin, Texas, precisely timed by varved sediments. Earth Planet. Sci. Lett. 66, 111-124.

Magaritz, M. \& Schulze, K. H. 1980: Carbon isotope anomaly of the Permian period. Contr. Sediment. 9, 269-277.

Magaritz, M. \& Turner, P. 1982: Carbon cycle changes of the Zechstein Sea: Isotopic transition zone in the Marl Slate. Nature 297, 389-390.

Marowsky, G. 1969: Schwefel-, Kohlenstoff- und SauerstoffIsotopenuntersuchungen am Kupferschiefer als Beitrag zur genetischen Deutung. Contr. Mineral. Petrol. 22, 290-334.

Maync, W. 1942: Stratigraphie und Faziesverhältnisse der oberpermischen Ablagerungen Ostgrönlands. Meddr Grønland 115(2), $128 \mathrm{pp}$.

Maync, W. 1961: The Permian in Greenland, in G. O. Raasch (ed) Geology of the Arctic. Toronto: Univ. Toronto, 214 223.

Perch-Nielsen, K., Birkenmajer, K., Birkelund, T. \& Aellen, M. 1974: Revision of Triassic stratigraphy of the Scoresby Land and Jameson Land Region, East Greenland. Bull. Gronlands geol. Unders. 109, 51 pp.

Scholle, P. A. \& Arthur, M. A. 1980: Carbon isotope fluctuations in Cretaceous pelagic limestones: Potential stratigraphic and petroleum exploration tool. Amer. Ass. Petrol. Geol. Bull. 64, 47-87.

Stauber, H. 1942: Die .Triasablagerungen von Ostgrönland. Meddr Grønland 132(1), 325 pp.

Surlyk, F., Piasecki, S., Rolle, F., Stemmerik, L., Thomsen, E. \& Wrang, P. in press: The Permian basin of East Greenland. in A. M. Spencer et al. (ed) Petroleum Geology of the North European Margin. London: Graham \& Trotham.

Taylor, S. R. 1983: A stable isotope study of the Mercia Mudstones (Keuper Marl) and associated sulphide horizons in the English Midlands. Sedimentology 30, 11-31.

Teichert, C. \& Kummel, B. 1973: Permian-Triassic boundary in the Kap Stosch area, East Greenland. Can. Soc. Petrol. Geol. Mem. 2, 269-285.

Veizer, J., Holser, W. T. \& Wilgus, C. K. 1981: Correlation of ${ }^{13} \mathrm{C} /{ }^{12} \mathrm{C}$ and ${ }^{34} \mathrm{~S} /{ }^{32} \mathrm{~S}$ secular variations. Geochim. Cosmochim. Acta 44, 579-587.

Visscher, H. 1973: The Upper Permian of Western Europe - A palynological approach to chronostratigraphy. Can. Soc. Petrol. Geol. Mem. 2, 200-219. 
Warrington, G. 1970: The stratigraphy and palaeontology of the 'Keuper' Series of the central Midlands of England. $Q$. J. Geol. Soc. Lond. 126, 183-223.
Wilgus, C. K. 1981: A Stable Isotope Study of Permian and Triassic Marine Evaporite and Carbonate Rocks, Western Interior, U.S.A. Ph.D. Dissertation, Univ, of Oregon, Eugene. 